\title{
The Assessment of Vocational Training, Monitoring \& Evaluation as the Main Determinants of Job Creation and Projects Sustainability
}

\author{
Habinshuti Patrice', Mudaheranwa Benjamin ${ }^{2}$, Habimana Theogene ${ }^{1}$, Mutambuka Deo ${ }^{1}$ \\ ${ }^{1}$ Regent University's Business Development Center - BDC Rwanda, Virginia Beach, Virginia, US \\ ${ }^{2}$ Christian University of Rwanda, Kigali, Rwanda, East Africa
}

\begin{abstract}
How to cite this paper: Habinshuti Patrice | Mudaheranwa Benjamin | Habimana Theogene | Mutambuka Deo "The Assessment of Vocational Training, Monitoring \& Evaluation as the Main Determinants of Job Creation and Projects Sustainability" Published in International Journal of Trend in Scientific Research and Development (ijtsrd), ISSN: 24566470, Volume-3 | Issue-3, April 2019, pp.1844-1848, URL: https://www.ijtsrd.c om/papers/ijtsrd23 600.pdf

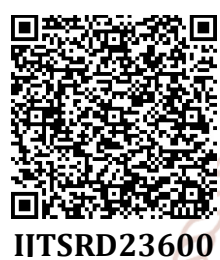

Copyright (C) 2019 by author(s) and International Journal of Trend in Scientific Research and Development Journal. This is an Open Access article distributed under the terms of the Creative Commons

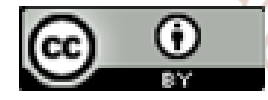

Attribution License (CC BY 4.0) (http://creativecommons.org/license s/by/4.0)

\section{ABSTRACT}

Due to the growing importance of the monitoring and evaluation all-over the world, many projects identified the benefits and are trying to establish it in their operations. But, according to Angelo (2008) lack of data auditing, internal control and effective information, continue to cause non-sustainable outcome of the youth projects. The general objective of the study is to analyze the contribution of monitoring and evaluation, vocational training on projects sustainability and job creation in Rwanda. Specific objectives are to identify the contribution of data auditing to the sustainability of projects in Rwanda; to examine how internal control influences the sustainability of projects in Rwanda and to ascertain the effect of effective information to the sustainability of projects in Rwanda. The findings could help policy makers in decision making and enable them put in place policies guiding running of projects in the country. This study adopted case study and descriptive design. The researcher targeted 7355 students from Iwawa Rehabilitation and Vocational Skills Development Centre (IRVSDC) that graduated in nine promotions, from 2010 up to 2016 and 50 staff of IRVSDC. The researcher used (Yamane, 1967) formula to determine sample size $n=98$ people. The 97 respondents were selected from 7355 students using convenience sampling method, while 1 staff was selected from 50 staffs purposively. The data collection instruments in this research were questionnaires and interviews. The data were analyzed using both descriptive and inferential statistics through SPSS software. This research used SPSS version 16 and found that the coefficient $r$ equal to 0.971 . This study concluded that the effects of effective information are youth's job creation, youth's income access, youth's decision-making, youth's self-reliance; and youth's leadership. This research also concluded that there is a positive correlation between M \& E mechanisms and project sustainability in Rwanda. The researcher recommended that projects should have M \& E in order to perform better. The researcher further recommends that the government of the republic of Rwanda should help vocational project to know the benefits of monitoring and evaluation.

KEYWORDS: monitoring, evaluation, vocational training, projects sustainability and job creation

\section{INTRODUCTION}

During the past 50 years, organizations worldwide in the public sectors have established (Binnendijk, 2011). Government projects have been occupying the role of main service providers over the past few years (Ashbaugh, 2004). Monitoring and evaluation ( $M$ \& E) has become an increasingly important tool within global efforts toward achieving environmental, economic and social sustainability (Mrosek, Balsillie \& Schleifenbaum, 2006). At national and international scales, sustainability criteria and indicators for M\&E are important tools for defining, monitoring and reporting on ecological, economic and social trends, tracking progress towards goals, and influencing policy and practices (Margoluis \& Salafsky, 2010).
Developed countries' projects, particularly those of the Organisation for European Co-operation and Development (OECD), have had as many as 20 or more years of experience in M\&E, while many developing countries are just beginning to use this key public management tool. The experiences of the developed countries are instructive, and can provide important lessons for developing countries (World Bank, 2004). Developing countries now perform some kind of regular monitoring and evaluation activities. These range from comprehensive national evaluation systems in countries such as India and Malaysia to basic monitoring of selected projects in many countries in Africa and the Middle East (Florin, 2011). In China, there were special officers in the government to control the duties of external auditing and 
internal auditing (Angus \& Mohammed, 2014). According to Abdulkadir (2014) the evidence shows that Kenya mostly relies on traditional and informal control structure to fulfill their welfare agendas.

According to Florin (2011)Monitoring and Evaluation is a process that helps improving performance and achieving results. According to Marcus (2005), project sustainability is defined as the capacity of a project to continue to deliver its intended benefits over an extended period of time. According to Robert, Thomas and Anthony (2005) project sustainability is the ability of the project manager to maintain either its success or social requirements to move from business as usual without changing lifestyles.

According to reports from World Bank (2014) 50 over 70\% of Rwanda population is the youth. According to Joseph, Eugene and Peter (2015) the challenges faced by the youths can be converted into enormous opportunities that oversee Rwanda moving into middle income country by the end of vision 2020. A total of 696 students from Iwawa Rehabilitation and Vocational Skills Development Centre (IRVSDC) graduated in 2014. Where 191 students completed training in carpentry, masonry 414 and 91 in tailoring. At the graduation ceremony, all graduates disclosed that they stopped all bad habits like drug abuse and theft; they revealed that they will be role models among peers in their respective villages, stressed that they are responsible of their personal decision to contribute positively in the society. Their training covered a period of sixteen months at Iwawa Island of Lake Kivu, Rutsiro District in the Western Province of Rwanda. The government set up the rehabilitation and vocational skills development center on Iwawa Island in 2010, from 2010 up to 2016; 7355 students have graduated in six promotions (Ministre of Youth and ICT, 2014).

\section{PROBLEM STATEMENT}

Due to the growing importance of the monitoring \& evaluation all-over the world, many youth projects identified the benefits and they are trying to establish it in their operations (Baker, 2011). But, according to Angelo (2008) lack of data auditing, internal control, and effective communication continue to cause non-sustainable outcome of the youth projects, because the outcomes of many projects are not benefited after being implemented. Where Chauvet, Collier, Fuster (2007) claimed that 39\% of World Bank projects were unsuccessful in 2010 and the projects failure rate at the World Bank was over 50\% in Africa until 2012.

And then, there are poor M\&E operations of youth projects that should be due to ineffective and inappropriate of data communication during evaluation, where the international development community's interest in benefit sustainability relates directly to the increasing evidence available in the late 1980 's and early 1990's that the expected sustainable benefits of many project investments had failed to materialize following the completion of various project (Marcus, 2005). Therefore, when projects fail to meet their desired sustainable objectives as planned, it becomes a big threat to both management and beneficiaries of the projects. Although, the Government of Rwanda, (2010) has established a programme of support with the United Nations for Analysis, Monitoring \& Evaluation, till now, the many of Government projects do not sustain their outcomes
(Ministry of Finance and Economic Planning [MINECOFIN], 2013).

This problem was found specifically on Iwawa Rehabilitation and Vocational Skills Development Centre (IRVSDC) established in 2010, where from 2010 up to 2014; 7355 students completed training in carpentry, masonry and tailoring have graduated in six promotions, but reports of Ministre of Youth and ICT reported that some of them did not use this skills in their socio-economic empowerment and Government programmes (Ministre of Youth and ICT, 2014). World Bank ( 2014) argued that, it will be impossible to reach the Millennium Development Goal targets, if the youths are not properly incorporated into Government programmes. Considering this observation, many project managers or owners do not carry out enough researches with accurate data during M\&E in Rwanda, hence, it was felt necessary to study the contribution of vocational training and $M$ \&E mechanisms to the projects sustainability and job creation in Rwanda.

\section{OBJECTIVES OF THE STUDY}

The general objective of the study was to assess the contribution of vocational training, monitoring and evaluation on projects sustainability and job creation in Rwanda.

1. To identify how data auditing contributes to the sustainability of Iwawa vocational training youth project in Rwanda;

2. To examine how internal control influences the sustainability of Iwawa vocational training youth project in Rwanda;

3. To ascertain the effect of effective information to the sustainability of Iwawa Vocational Training Youth Project in Rwanda.

\section{RESEARCH QUESTIONS}

1. What is the contribution of data auditing to the sustainability of Iwawa vocational training youth project in Rwanda?

2. How internal control influences the sustainability of Iwawa vocational training youth project in Rwanda?

3. Is there any effect of effective information to the sustainability of Iwawa vocational training youth project in Rwanda?

\section{RELATED STUDIES}

Tache (2011) carried out a study called developing an Integrated M \& E flow for Sustainable Investment Projects in Romania. the objective of the study was to develop a general integrated flow, encompassing both a project monitoring system and also a project evaluation system for the investment projects involving economic objectives, as well as cross-cutting social and environmental targets. The whole approach was being presented as a flowchart, which highlights the intimate relationship between the monitoring and evaluation processes, and provides a formal framework for performing a logical monitoring and evaluation process, taking into account simultaneously the economic, social and environmental perspectives, within an investment project. The study used critical analysis and found that both the estimated advantages and the disadvantages of such a managerial tool, opening new perspectives for developing further improved models and systems. 
Gilbert, Ron, and Schipper (2014) analyzed the sustainability in project management competencies: analyzing the competence gap of project managers in Netherlands. The objective was to analyze the coverage of the competencies required for considering sustainability aspects, in the standards of project management competencies. The study also aimed to specify the competence gap of project managers with regards to sustainability, and to provide guidance on how to close this gap. Thestudy therefore made specific suggestions on how the standards of project management competencies should develop in order to prepare project managers for their pivotal role in realizing sustainability of organizations. The stuy used documentary analysis and conclued that Projects are "instruments of change" within organizations, which play an important role in the realization of sustainable business processes and practices. Project managers are therefore important "change agents" in organizations that have a strong influence on the sustainability of organizations.

Zubair, Muhd, Majid and Mushairry ( 2006) carried out a study called a systematic approach for monitoring and evaluating the construction project progress. The objective of this study was to identify techniques that can be used in the construction industry for monitoring and evaluating the physical progress, and also to establish how current computer technology can be utilised for monitoring the actual physical progress at the construction site. They discusseed the results of questionnaire survey conducted within Malaysian Construction Industry and suggests a prototype system, namely Digitalising Construction Monitoring (DCM). DCM prototype system integrates the information from construction drawings, digital images of construction site progress and planned schedule of work. Using emerging technologies and information system the DCM re-engineer the traditional practice for monitoring the project progress. The study revealed that the system can automatically interpret drawings of buildings and extract data on its structural components and store in database. It can also extract the engineering information from digital images and when these two databases are simulated the percentage of progress can be calculated and viewed in Microsoft Project automatically.

Udensi, Daasi, Gibson, Emah and Zukbee 2013) analysed youth participation in Community Development (CD) programmes in cross river state: Implications for sustainable youth development in Nigeria. The study used both questionnaires and interview and then poses that through active participation and encouragement; youths can be effective instrument for CD programmes and may take ownership as well. With field-based data from Cross River State, South-South Nigeria, the study examines the extent and strategies to which the youth can be meaningfully engaged in CD programmes and presents an evaluation of the challenges facing them in that direction.

Karanja (2014) analyse the influence of management practices on sustainability of youth income generating projects in Kangema District, Murang'a County, Kenya. The purpose of the study was to assess the influence of management practices on sustainability of the youth income generating projects. The specific objectives were to establish influence of Leadership on sustainability of youth income generating projects in Kangema District, to establish influence of training on sustainability of youth income generating projects in Kangema District, to establish the influence of financial management on sustainability of youth income generating projects in Kangema District, to assess the influence of monitoring and evaluation on sustainability of youth income generating projects in Kangema District. It focused on training, Monitoring \&Evaluation, Leadership and financial management aspects in relation to project sustainability. Descriptive survey design was adopted with 13 youth groups selected through stratified sampling where the chairperson and member of each group included in the sample. Two groups were involved in focused group discussion. District youth officer was also in terviewed. Data was analyzed using descriptive statistics. The study revealed that, sound financial management, appropriate training, leadership and effective monitoring and evaluation influence the sustainability of the youth projects.

Walter and Henry (2014) analysed the role of participatory management in the Sustainability of constituency development fund projects in Kenya with refence of Maragua Constituency. The purpose of the study was to determine contribution of participatory management in influencing determinants of Constituency Development Fund projects' sustainability. The research study adopted a case study design with target population Being Constituency Development Fund (CDF) project stakeholders within Maragua constituency in Kenya. Semi-structured questionnaire was administered to a sample of 89 stakeholders randomly selected from stratified target population distributed across the constituency. Descriptive and inferential data analysis was then applied to determine and assess the relationships through SPSS Version 20.0. The analysis showed that Participatory Management is crucial in inculcating the determinants of sustainability in CDF projects. However, the findings further showed that there was very little stakeholder participation in the entire cycle management of the projects within Maragua Constituency which contributed to low ownership of the projects.

Joseph, Eugene and Peter (2015) analyzed factors, strategies, polices \& stakeholders influence for youth performances in agri-business projects in Bugesera District Rwanda. The general objective of this study was to assess the level of involvement of the youth in Agri-business projects for employment and poverty reduction in Bugesera District of Rwanda. Descriptive cross-sectional study design was employed using a stratified sampling technique. Target population was the youth aged (15-35) years who are residence of Bugesera District and engaged in Agri-Business activities whose numbers is estimated to be 142,162 . A sample size of 400 youths was involved in this research. Selfadministered Questionnaire with open ended questions was used to collect the data. Data was analyzed using SPSS tool version 21. Correlation analysis showed that there was a positive significant relationship between youth performance in agribusiness, training, motivation and income generated.

\section{RESEARCH METHODOLOGY}

This study adopted case study descriptive design to get results expected from this study. The descriptive research design facilitated the researcher to establish, analyze and interpret the contribution of monitoring and evaluation on sustainability of projects in Rwanda. While the case study facilitated in depth analysis of the research problem. The researcher targeted 50 staff and 7355 students from Iwawa Rehabilitation and Vocational Skills Development Centre 
(IRVSDC) have graduated in nine promotions, from 2010 up to 2016. The targeted population was 7405 people (Ministry of Youth and ICT, 2015). The sample size of the study was the proportionality between staff and students from Iwawa Rehabilitation and Vocational Skills Development Centre (IRVSDC) as follows;

$$
n=\frac{N}{1+N e^{2}}=\frac{7 / 405}{1+7405 * 0.1^{2}}=98
$$

Where, $\mathrm{N}$ : Target population $=4570$, e $:$ Error of precision $=$ $10 \%$, and $\mathrm{n}=98$ sample size .

Sample for staff: $\frac{50 \cdot 98}{7405}=1$

Sample for students: $\frac{7355 * 99}{7405}=97$

The study used both primary and secondary data collection methods. Primary data collecting methods included use of questionnaire and interview, while secondary data collecting methods included reviewing reports of Iwawa.

Quantitative and qualitative data analysis techniques were used. Process of data involved editing, coding, tabulation and classification of data in order to make them easily understandable. Quantitative data were analysed using both descriptive and inferential statistics through Statistical Packaging for Socio Sciences (SPSS) software. The data were presented in form of figure and tables. Pearson correlation coefficient were used to establish relationship between variables.

\section{SUMMARY OF FINDINGS AND CONCLUSION}

According to the first research question, the findings of the study reveal that the management of the Iwawa is entrusted with public resources and loaded with the responsibility of managing these resources effectively and efficiently, this influence the sustainability of the project. Internal audit and $M \& E$ are the cornerstone for achieving objectives set and signed by Iwawa management. Because there is some form of independent audit activities in Iwawa to evaluate the full range of activities. By providing unbiased, objective assessments of whether public resources are responsibly and effectively managed to achieve sustainability of the project, auditors and monitors help government organizations to achieve accountability and integrity, improve operations, and instill confidence among citizens and stakeholders. M\&Er's role addresses whether project managers are doing what they are supposed to do and serves to detect and prevent public corruption. It also helps decision-makers by providing an independent assessment of project sustainability.

According to the second research question, this study concluded that respondents were satisfied with monitoring and evaluation, meaning that they wish and are free to continue working with the project, hence monitoring and evaluation contribute to the sustainability of the project and that project values in the project are all related to ensuring that all the factors that can contribute to sustainability of the project are given consideration and they all rotate on how best project performing. Therefore monitoring and evaluation are essential in enhancing sustainability of project. According to the third research question, this study concluded that the effects of effective information are youth's job creation, youth's income access, youth's decisionmaking;, youth's self-reliance; and youth's leadership. This research also concluded that there is a positive correlation between Monitoring \& Evaluation mechanisms and project sustainability in Rwanda.

\section{RECOMMENDATIONS}

The researcher recommended that projects should have M \& $\mathrm{E}$ in order to perform better. The researcher further recommends that the government of the republic of Rwanda should help vocational project to know the benefits of monitoring and evaluation. Leaders in various projects should ensure that they manage project in the best ways that are able to lead and to improve sustainability Last but not least, the researcher recommended other project that should learn from Iwawa on how best to sustain through improved M \& E. The researcher recommended that all projects should concentrate on M\&E in order to improve their sustainability; this is so because Monitoring and evaluation helps projects to know the environment in which they are operating and how to go about it.

\section{ACKNOWLEDGMENT}

It is my pleasure to thank several people who contributed to the success of this work. We are particularly grateful to our supervisor Habimana Theogene for his encouragement, steady, wise guidance and diligent oversight that made this effort possible. He provided a lot of constructive ideas, inspiration and encouragement throughout. We are grateful to the management and academic staff of Regent University's Business Development Center / BDC Rwanda for their support and their commitment for the education of Rwandans in advancing knowledge and practice in the real world of development.

\section{REFERENCES}

[1] Abdulkadir, H. S. (2014). Challenges of implementing internal control systems in Non-Governmental Organizations (NGO) in Kenya: A case of Faith-Based Organizations (FBO) in Coast Region. Journal of Business and Management, Vol.16(3), PP 57-62.

[2] Andrew B. Bernard, Bradford Jensen,Stephen,J, Redding,J \& Peter K. Schott. (2007). Projects sustainability in International Trade. Dartmouth: Tuck School of Management at Dartmouth \& NBER.

[3] Angelo, L. E. (2008). Auditor Size and Auditor Quality. Journal of Accounting \& Economics., Vol.3, PP.183-199.

[4] Angus, O. U \& Mohammed, I. K. (2014). Effectiveness of Internal Audit as Instrument of Improving Public Sector Management . Journal of Emerging Trends in Economics and Management Sciences, Vol.2(4), PP. 304309.

[5] Ashbaugh, H. (2004). Ethical Issues Related to the Provision of Audit and Non-audit Services: Evidence from Academic Research. Journal of Business Ethics, PP.143-148.

[6] Baker, N. (2011). Raising internal audit's potential. London: Internal Auditors inc.

[7] Binnendijk, A. (2011). Results based management in the development co-operation agencies: a review of experience. New York: DAC Working Party. 
International Journal of Trend in Scientific Research and Development (IJTSRD) @ www.ijtsrd.com eISSN: 2456-6470

[8] Florin, T. (2011). Developing an Integrated Monitoring and Evaluation Flow for Sustainable Investment Projects. Romania: The Bucharest Academy of Economic Studies.

[9] Gilbert,A. J., \& Ron, J. S. (2014). Sustainability in Project Management Competencies: Analyzing the Competence Gap of Project Managers. Journal of Human Resource and Sustainability Studies, Vol.2(4), PP.40-58..

[10] Joseph, J. N., Eugene, N., \& Peter, M. (2015). Factors, Strategies, Polices \& Stakeholders Influence for Youth Performances in Agri-Business Projects in Bugesera District Rwanda. The International Journal Of Business \& Management, Vol.3(9), PP.459 - 468.

[11] Karanja, G. (2014). Influence of management practices on sustainability of youth income generating projects in Kangema District, Murang'a County, Kenya. International Journal of Education and Research, Vol.2(2), PP.1 - 12.

[12] Marcus, D. I. (2005). project sustainability manual. Oregon, United State: Portland State University.

[13] Margoluis, R. \& Salafsky, N. (2010). Measures of Success. Washington, D. C: Island Press.

[14] Ministre of Youth and ICT. (2014). Annual reports of Ministre of Youth and ICT. Kigali: Ministre of Youth and ICT.

[15] Ministry of Finance and Economic Planning [MINECOFIN]. (2013). Ministry of Finance and Economic Planning (MINECOFIN) annual report 203. Kigali, Rwanda: Goverment of Rwanda.

[16] Mrosek,T., Balsillie, D., \& Schleifenbaum, P. (2006). Field testing of a criteria and indicators system for sustainable forest management at the local level.

[17] Zimbabwe: The Case Of Gweru Young People's Enterprise (GYPE). Journal of Sustainable Development in Africa, Vol.16(5), PP.138 - 144.

[18] Paulinus, W. I. \& Iyenemi, I. K. (2014). M \& E Rural Water Supply Projects And Sustainable Development In Nigeria. Journal of Sustainable Development in Africa, Vol.16(1), PP.56 - 68.

[19] Qaisar, Ab.\& Javid, I. (2012). Internal Control System as mechanisms of M\&E: Analyzing Theoretical
Perspective and Practices. Middle-East Journal of Scientific Research, Vol.12(4), PP. 530-538.

[20] Renzio,D., Paolo, David, B., Andrew, R., \& Zaza,C. (2005). "Incentives for Harmonisation in Aid Agencies: A Report to the DAC Working Party on Aid Effectivenss.". London: Overseas Development Institute.

[21] Robert, G. Marxa,B. Alia,M. Lois, H., Edward, C., Jonesb, Russell, F.,Warrena. (2003). A comparison of two time intervals for test-retest reliability of health status instruments. Journal of Clinical Epidemiology, Vol.56, PP.730-735.

[22] Roger, E. and Tim, M. (2008). Official Statistics and Monitoring and Evaluation Systems in Developing Countries. Paris: Institute of Statistics and Monitoring.

[23] Silva, L. L. (2009). Monitoring the success of stakeholder engagement. Cardiff: Canberra.

[24] Stem, C., Margoluis, R., Salafsky, N., \& Brown, M. (2005). Monitoring and evaluation in conservation. USA: Institute of Monitoring and evaluation.

[25] Tache, F. (2011). Developing an Integrated Monitoring and Evaluation Flow. Journal of Economia. Seria Management, PP.381 - 391.

[26] Udensi, L. O., Daasi, Gibson, L.K., Emah, D. S.\&, Zukbee, S. A. (2013). Youth Participation in Community Development (CD) Programmes in Cross River State: Implications for Sustainable Youth Development in Nigeria. Journal of Humanities And Social Science, Vol.13(5), PP. 61-67.

[27] World Bank. (2004). Development of monitoring and evaluation. Washington DC: World Bank.

[28] World Bank. (2010). Monitoring and Evaluation: Some tools, methods and approaches. Washington DC: World Bank.

[29] World Bank. (2014). World population report Washington: D.C.: World Bank.

[30] Yamane, T. (1967). Statistics: An Introductory Analysis. New York: Harper and Row.

[31] Zubair, A. M., Muhd, Z. A. Majid \& Mushairry, M. (2006). A Systematic Approach For Monitoring And Evaluating The Construction Project Progress. Journal - The Institution of Engineers, Vol.67(3), PP.26 - 32. 